\title{
DISRUPTIVE TECHNOLOGY THROUGH SATELLITE IMAGERY BIG DATA IN DISASTER RISK REDUCTION: OPPORTUNITY AND CHALLENGE
}

\section{DISRUPSI TEKNOLOGI MELALUI BIG DATA CITRA SATELIT DALAM PENGURANGAN RISIKO BENCANA: PELUANG DAN TANTANGAN}

\author{
Dian Nuraini Melati ${ }^{1}$ \\ ${ }^{1}$ Pusat Teknologi Reduksi Risiko Bencana (PTRRB), Kedeputian TPSA - Badan Pengkajian dan \\ Penerapan Teknologi (BPPT) \\ Gedung Geostech, Lantai 1, Kompleks Puspiptek Serpong, Tangerang Selatan \\ e-mail: dian.nuraini@bppt.go.id
}

\begin{abstract}
The development of current massive technology plays an important role in the field of disaster risk reduction and disaster management. In particular, the issue of disruptive technology in which the emerging of new technologies comes with big disruption in many fields. For instance, the development on using satellite imagery big data for disaster management to reduce the disaster risk. The unique characteristics of big data i.e. volume, velocity, and variety stimulate this study to obtain more information on the big data processing and analyze the opportunities and challenges of satellite imagery in the case of disaster risk reduction through literature reviews. The huge amount of data and the ability for real-time analysis provide capabilities on time series analysis and positive impact on disaster detection, monitoring, and prediction. However, such technology creates disruption due to the change on using and anlysing the data based on cloud environment. Issues on the technology mastery and also data security on the resulted information at cloud environment might arise. Nonetheless, the use of satellite imagery big data will remain vastly developed and is able to promote the development of satellite imagery technology.
\end{abstract}

Keywords: Remote sensing, disaster risk reduction, big data, cloud computing

\begin{abstract}
Abstrak
Peran perkembangan teknologi yang masif saat ini tidak diragukan lagi menjadi sangat penting dalam kegiatan pengurangan risiko bencana dan manajemen bencana. Terutama melalui isu disrupsi teknologi di mana munculnya teknologi-teknologi baru yang membawa dampak dengan lingkup disrupsi (gangguan) yang besar pada segala bidang. Salah satunya adalah perkembangan pemanfaatan big data citra satelit dalam manajemen bencana yang turut berperan dalam pengurangan risiko bencana. Dengan karakteristiknya yang unik meliputi ukuran (volume), kecepatan (velocity), dan keberagaman (variety), studi ini menggali informasi mengenai proses pengolahan big data citra satelit dan mengkaji sejumlah peluang pemanfaatan big data citra satelit dalam pengurangan risiko bencana beserta tantangan yang dihadapi melalui studi pustaka. Ketersediaan data yang cukup besar serta kemampuan analisis yang real-time mampu mendukung analisis multi waktu dan memberikan dampak yang positif dalam deteksi, pemantauan, dan prediksi suatu kejadian bencana. Hal ini sangat dibutuhkan untuk manajemen suatu bencana yang efektif dan efisien sehingga pengurangan risiko terhadap kejadian suatu bencana dapat tercapai. Tentunya perkembangan penggunaan big data citra satelit ini membawa disrupsi teknologi tersendiri. Salah satunya adalah membawa perubahan dalam hal penggunaan dan analisis data yang berbasis pada cloud environment. Isu penguasaan teknologi dan juga keamanan informasi yang dihasilkan menjadi tantangan tersendiri. Namun demikian, dengan segala peluang dan tantangan yang ada, pemanfaatan big data citra satelit akan semakin berkembang pesat dan turut mempromosikan kemajuan teknologi citra satelit.
\end{abstract}

Kata kunci: Penginderaan jauh, pengurangan risiko bencana, big data, komputasi awan 


\section{PENDAhULUAN}

\subsection{Latar Belakang}

Bencana merupakan kombinasi dari bahaya dan kerentanan yang akan memberikan dampak yang besar terutama bagi komunitas yang rentan terhadap bahaya. Selain menyebabkan terancamnya kehidupan manusia, bencana juga mempengaruhi kondisi ekonomi. Karakteristik utama dari bencana adalah tidak mudah untuk diprediksi, sumber daya yang terbatas pada area terdampak, dan terjadinya dinamika perubahan pada lingkungan (Celik dan Corbacioglu, 2010; Yu et al., 2018b). Karakteristik yang tidak terprediksi menunjukkan bahwa dampak buruk pada manusia serta sarana dan prasarana saat terjadi bencana tidak dapat diprediksi secara akurat. Selanjutnya, sumber daya yang terbatas sebagai akibat tidak terprediksinya bencana mengakibatkan alokasi sumber daya sebelum kejadian menjadi sulit. Sedangkan perubahan yang dinamis dapat terjadi sebagai akibat timbulnya perpindahan orang dan kerusakan yang terjadi oleh karena suatu bencana.

Secara global, 315 kejadian bencana alam di tahun 2018 telah menyebabkan sekitar 68 juta orang terdampak, 11.804 orang meninggal, dan kerugian sekitar 131,7 miliar dolar Amerika (CRED, 2019). Agenda Sustainable Development Goals (SDGs) telah meningkatkan kesadaran pentingnya manajemen bencana, terutama ditunjukkan pada empat dari 17 tujuan SDGs yang telah ditetapkan oleh PBB. Keempat tujuan tersebut di antaranya yaitu tujuan ke 1, 2, 11, dan 13 yang menunjukkan pentingnya negara dan komunitasnya menghadapi tantangan terkait dengan bahaya dan bencana (ITU, 2019). Dalam hal peningkatan kemampuan untuk pengurangan risiko bencana dan manajemen bencana, perkembangan teknologi telah maju secara masif saat ini. Terutama melalui isu disrupsi teknologi untuk pengurangan risiko bencana dan manajemen bencana.

Istilah disrupsi teknologi telah ada sejak kurang lebih dua dekade yang lalu. Disrupsi teknologi mengacu pada munculnya teknologiteknologi baru yang membawa dampak pada segala bidang yang telah ada dengan lingkup disrupsi (gangguan) yang besar (Christensen et al., 2015). Disrupsi teknologi, seperti artificial intelligence (Al), the Internet of Things (loT), dan Big Data, serta inovasi-inovasi terkait seperti robotik dan teknologi drone telah berpengaruh pada perubahan di segala bidang termasuk pengurangan risiko bencana dan manajemen bencana. Pada studi kali ini, akan lebih fokus pada peranan big data, khususnya data citra satelit pada pengurangan risiko bencana. Terkait hal tersebut, big data memiliki karakteristik antara lain ukuran (volume), kecepatan (velocity), dan keberagaman (variety) (Goodchild, 2013). Dalam hal ukuran, big data menunjukkan ukuran yang lebih besar dari sebelumnya atau lebih besar dari kemampuan yang ada saat ini. Untuk itu, proses pengolahan data membutuhkan media penyimpanan yang besar. Sedangkan kecepatan menunjukkan bahwa big data dapat diperoleh mendekati real time dari sumber-sumber online. Karakteristik selanjutnya yaitu sifat keberagaman di mana big data terdiri dari format data yang beragam tergantung berbagai macam sumber data.

Dalam konteks tersebut, kajian ini melakukan studi literatur mengenai disrupsi teknologi oleh big data citra satelit terkait dengan proses pengolahan, peluang pemanfaatan dalam pengurangan risiko bencana, serta tantangan yang dihadapi dari perkembangan big data citra satelit.

\subsection{Tujuan Penelitian}

Penelitian dilakukan untuk mengetahui peran disrupsi teknologi, khususnya big data citra satelit dalam pengurangan risiko bencana. Dalam hal ini akan dilakukan pengkajian mengenai peluang dan tantangan dalam implementasi teknologi terkait dalam pengurangan risiko bencana.

\section{BAHAN DAN METODE}

\subsection{Bahan}

Bahan yang digunakan dalam studi ini adalah menggali artikel-artikel terkait baik nasional maupun internasional. Artikel tersebut digunakan sebagai referensi dalam mengulas peran disrupsi teknologi melalui big data citra satelit dalam pengurangan risiko bencana.

\subsection{Metode}

Studi dilakukan dengan langkah-langkah sebagai berikut:

1. Melakukan studi pustaka baik mengenai data, informasi, dan kajian-kajian terkait yang telah dilakukan melalui penelusuran buku, laporan dari institusi terkait, maupun artikel ilmiah terkait. 
2. Membuat deskripsi mengenai proses pengolahan big data citra satelit.

3. Membuat deskripsi mengenai peluang pemanfaatan big data citra satelit dalam pengurangan risiko bencana.

4. Membuat deskripsi mengenai tantangan implementasi big data citra satelit dalam pengurangan risiko bencana.

\section{HASIL DAN PEMBAHASAN}

\subsection{Disrupsi Teknologi Pemanfaatan Citra Satelit}

Citra satelit sangat bermanfaat dalam memberikan informasi baik sebelum maupun sesudah kejadian bencana. Citra satelit ini memiliki kelebihan yaitu pemantauan yang cukup luas dan juga perekaman multi waktu. Pada saat sebelum kejadian bencana, citra satelit dapat bermanfaat dalam mendukung sistem peringatan dini. Selain itu juga dapat memberikan informasi perubahan sebelum dan setelah kejadian bencana. Informasi setelah terjadinya bencana ini sangat penting untuk diperoleh. Citra satelit dengan resolusi spasial tinggi dapat memberikan informasi kerusakan pada daerah yang terdampak bencana. Selain itu juga, dapat memberikan informasi bagi kegiatan tanggap darurat.
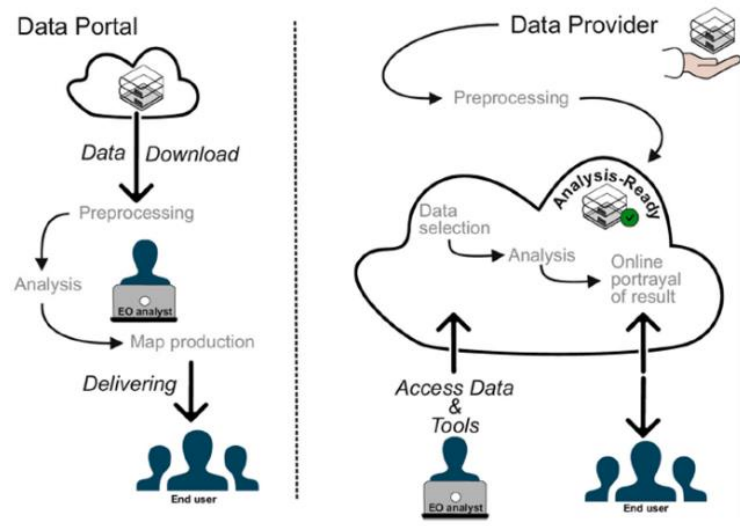

Gambar 1. Diagram Alir Perubahan dalam Analisis Citra Satelit. Gambar Kiri Menunjukkan Cara Lama di mana Analisis Dilakukan Secara Lokal dengan Mengunduh Data, Gambar Kanan Menunjukkan Cara Analisis dengan Menggunakan Big Data. (Sumber: Sudmanns et al., 2019)

Citra satelit telah banyak digunakan dalam pengurangan risiko bencana termasuk identifikasi permukiman, kajian risiko banjir dan longsor, dan juga peringatan terhadap bahaya kebakaran hutan. Saat ini, isu mengenai big data citra satelit tidak hanya terkait dengan kuantitasnya saja baik itu dari sisi ukuran, kecepatan, dan keberagaman. Namun demikian, juga terkait dengan dirupsi perubahan yang mengubah cara pengguna dalam memanfaatkan data citra satelit dan cara menghasilkan informasi hasil analisis (Sudmanns et al., 2019). Gambar 1 menunjukkan terjadinya disrupsi teknologi dalam pemanfaatan citra satelit. Di mana seperti diketahui, analisis citra satelit secara konvensional dilakukan dengan cara mengunduh citra satelit. Selanjutnya pengolahan data dilakukan secara lokal oleh analis. Hasil akhir analisis yang berupa peta kemudian didistribusikan pada pengguna akhir. Sedangkan di era pemanfaatan big data citra satelit, pemberi data telah menyediakan data citra satelit yang telah siap untuk digunakan untuk analisis lebih lanjut. Dalam hal ini, pra-pengolahan data telah dilakukan oleh penyedia data. Selanjutnya analis data dapat melakukan pengolahan dengan menggunakan perangkat yang disediakan oleh penyedia data tersebut. Analisis dilakukan berbasis pada komputasi awan (cloud computing). Selanjutnya hasil akhir analisis tersedia pada cloud environment tersebut yang memungkinkan untuk diakses oleh pengguna akhir. Pengguna dapat berinteraksi secara langsung pada sistem tersebut, seperti melakukan pemilihan warna, filterisasi terhadap waktu maupun posisi geografis.

Google Earth Engine (GEE) (Gorelick et al., 2017) merupakan penyedia big data terkait dengan data-data citra satelit maupun spasial lainnya. Data-data tersebut tersedia pada cloud environment, di mana pengguna tidak perlu mengunduh data. Selain itu, pengguna juga dapat mengunggah data spasial.

\subsection{Analisis Big Data Citra Satelit}

Analisis big data citra satelit meliputi penyiapan, analisis, hingga visualisasi data dalam jumlah besar baik itu data multi waktu maupun data spektral yang meliputi berbagai jenis data (Kempler dan Mathews, 2017). Pemrosesan data yang diperoleh merupakan tantangan yang besar baik itu dari sisi ukuran (volume), kecepatan (velocity), dan keberagaman (variety). Berikut ini akan dijelaskan berbagai hal terkait dengan analisis big data citra satelit. 


\subsubsection{Pra-pengolahan data}

Pra-pengolahan data meliputi pemeriksaan terhadap data mentah sesuai dengan tujuan penelitian, baik itu mengenai konsistensi maupun data-data lain yang tidak diperlukan sebelum pemrosesan data lebih lanjut. Salah satu contoh adalah melakukan eliminasi terhadap tutupan dan juga bayangan awan pada citra penginderaan jauh sistem optik yang sangat dipengaruhi oleh tutupan awan.

Selanjutnya, metode transformasi juga sangat diperlukan sebelum melakukan proses analisis lebih lanjut. Sebagai contoh adalah melakukan normalisasi terhadap citra satelit dengan perekaman multiwaktu. Hal ini sangat diperlukan pada analisis perubahan yang menggunakan lebih dari satu perekaman citra, di mana citra yang direkam pada waktu yang berbeda tersebut sangat dipengaruhi oleh kondisi atmosfer.

\subsubsection{Pengolahan data}

Setelah pra-pengolahan data, selanjutnya pengolahan data dilakukan untuk menjawab berbagai hal terkait tujuan penelitian yang dilakukan. Beberapa metode dalam pengolahan data dapat dikelompokkan menjadi model simulasi dan prediksi, statistik, pembelajaran mesin (machine learning), dan pembelajaran mendalam (deep learning) (Yang et al., 2019).

\section{a. Model simulasi dan prediksi}

Data citra satelit yang dikombinasikan dengan pemodelan numerik telah banyak digunakan untuk simulasi dan prediksi mengenai fenomena yang akan terjadi di masa yang akan datang. Sebagai contoh, pemodelan deforestasi menggunakan citra satelit multi waktu (Melati, 2019). Penelitian tersebut menggunakan citra satelit dengan perekaman berbeda waktu untuk pemantauan deforestasi. Dari informasi perubahan tutupan yang ada, dilakukan simulasi dan prediksi tutupan hutan di waktu yang akan datang.

\section{b. Model statistik}

Model statistik dapat digunakan untuk mengetahui hubungan suatu variabel di lapangan dengan data citra satelit. Data yang dimaksud tersebut yaitu informasi spektral dari citra satelit. Kemampuan citra satelit dalam merekam obyek di muka bumi, dengan cakupan yang luas memungkinkan kita untuk melakukan pengamatan fenomena tertentu di muka bumi tanpa harus mengamati secara langsung suatu obyek di lapangan. Dengan metode pengambilan sampel pada daerah penelitian terhadap atribut suatu obyek, maka dapat dibuat kesimpulan mengenai fenomena yang diamati berdasarkan model statistik pada seluruh lokasi penelitian. Pemanfaatan model statistik juga dapat digunakan untuk ekstrapolasi suatu atribut penelitian. Sebagai contoh penelitian biomasa karbon pada hutan tropis. Dengan mengetahui hubungan atribut biomasa hasil pengukuran di lapangan pada lokasi sampel terpilih. Maka dapat dilakukan ektrapolasi nilai biomasa pada seluruh cakupan daerah penelitian. Hal ini dapat dilakukan dengan mengetahui hubungan melalui model statistik, misalnya regresi linear, antara biomasa di lapangan dengan nilai spektral citra satelit pada lokasi sampel tersebut.

\section{c. Pembelajaran mesin (machine learning)}

Sebagai hasil dari perkembangan kecerdasan buatan (Artificial Intelligence), metode pembelajaran mesin mengembangkan model-model yang didasarkan pada karakteristik hasil pembelajaran (Sellars et al., 2013). Pembelajaran tersebut didasarkan pada data empiris yang kemudian digunakan untuk membuat kesimpulan terhadap suatu masalah yang tidak diketahui dan juga untuk menemukan pola yang tidak dikenali. Salah satu contoh adalah metode pembelajaran mesin Random Forest (Breiman, 2001) untuk pemanfaatan klasifikasi tutupan lahan. Random Forest menentukan suatu kelas dari suatu kategori kelas tutupan lahan berdasarkan data sampel dari lapangan. Dari data sampel tersebut, kemudian dilakukan pembelajaran mesin mengenai pola keterkaitan antara data sampel dengan nilai spektral citra satelit. Selanjutnya berdasarkan suara (voting) terbanyak, maka dapat diambil kesimpulan mengenai kategori kelas tutupan lahan tertentu.

\section{d. Pembelajaran mendalam (deep learning)}

Pembelajaran mendalam ini merupakan hasil dari perkembangan pembelajaran mesin yang memiliki kemampuan memberikan hasil yang lebih detil terhadap ekstraksi citra satelit (Manning, 2015). Sebagai hasil dari kemampuannya yang baik dalam mengoptimasi parameter, metode ini telah mencapai keberhasilan dalam proses klasifikasi citra satelit. Salah satu contoh metode ini adalah convolutional neural networks (CNNs). Selain itu, pemanfaatan metode ini juga mampu meningkatkan efisiensi komputasi (Wang et al., 2018). 


\subsection{Peluang Pemanfaatan Big Data Citra Satelit dalam Pengurangan Risiko Bencana}

a. Analisis deteksi dan pemantauan

Deteksi dan pemantauan bencana yang efektif dapat mengurangi risiko bencana yang timbul. Salah satu sumber utama dari big data untuk deteksi dan pemantauan bencana adalah citra satelit yang tersedia dalam berbagai resolusi spasial dan temporal dengan akurasi yang cukup baik (Yu et al., 2018b). Citra satelit multi waktu dengan perekaman pada lokasi yang sama tetapi dengan waktu berbeda sangat bermanfaat dalam deteksi dan pemantauan bencana. Hal ini dapat memberikan masukan yang bermanfaat bagi manajemen bencana yang lebih efektif. Salah satu contoh adalah deteksi dan pemantauan bencana kebakaran hutan.
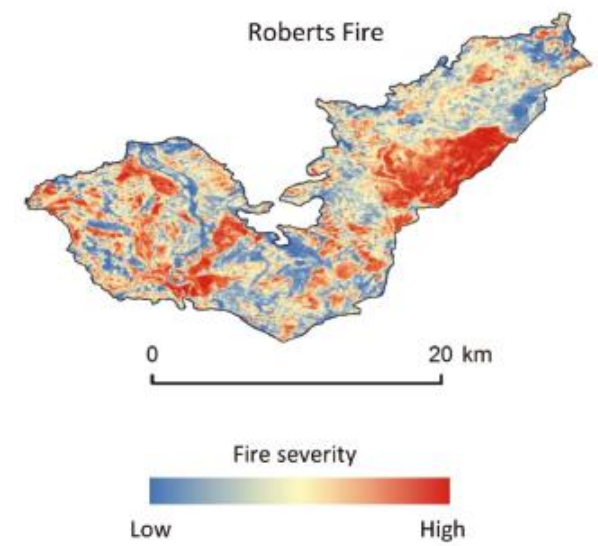

Gambar 2. Hasil Analisis Tingkat Kebakaran Lahan (Sumber: Parks et al., 2018)

Parks et al. (2018) melakukan studi untuk mendeteksi dan memantau tingkat kebakaran berdasarkan data Landsat multi waktu menggunakan platform Google Earth Engine (Gambar 2). Berdasarkan metode yang diaplikasikan, penulis menunjukkan bahwa pendekatan tersebut menghasilkan analisis kebakaran lahan dengan cara lebih mudah dan cepat. Selanjutnya berdasarkan hasil validasi, hasil analisis statistik menunjukkan tingkat validasi yang lebih baik.

\section{b. Analisis prediksi}

Bencana alam sangat sulit untuk diprediksi karena kompleksitas yang terkait dengan fenomena fisik dan variabilitas parameterparameter terkait (Yu et al., 2018b). Pendekatan yang banyak digunakan saat ini dalam prediksi bencana alam sangat bergantung pada pemodelan terhadap parameter terkait. Berkembangnya model pembelajaran mesin (machine learning) dan juga pembelajaran mendalam (deep learning), banyak digunakan dalam prediksi fenomena bencana alam. Sebagai contoh adalah prediksi bencana banjir dan longsor.

Salah satu studi yaitu dengan menggunakan metode pembelajaran mesin, dan platform Google Earth Engine yang menyediakan citra Landsat multi waktu. Yu et al., (2018a). Studi tersebut melakukan pemodelan untuk identifikasi kejadian longsor berdasarkan metode deteksi perubahan menggunakan pembelajaran mesin random forest. Studi tersebut dilakukan pada periode 2012-2016, di mana dilakukan sintesis citra Landsat setiap tahunnya. Hasil identifikasi longsor berdasarkan sintesis citra Landsat beserta data Digital Elevation Model (DEM) digunakan untuk memprediksi kejadian longsor di tahun berikutnya. Pemodelan ini memberikan hasil dengan akurasi yang cukup baik. Namun demikian, pada area dengan kejadian longsor yang sedikit maka akurasi menjadi menurun sebagai akibat sedikitnya training sample yang digunakan dalam pemodelan.

\section{c. Analisis risiko}

Dalam analisis risiko, citra satelit memiliki peranan penting dalam melakukan identifikasi lokasi dan risiko dari infrastruktur terhadap suatu kejadian bencana. Perkembangan citra satelit saat ini dengan resolusi spasial yang sangat tinggi dan juga aerial foto hasil perekaman drone sangat membantu dalam identifikasi obyek-obyek vital pada suatu daerah dalam cakupan yang luas. Sebagai contoh adalah kajian mengenai identifikasi banjir yang dilakukan oleh Uddin et al. (2018). Studi tersebut bertujuan untuk memetakan genangan banjir dan juga area yang memiliki potensi rusak sebagai akibat banjir dalam mendukung pengurangan risiko bencana banjir di daerah penelitian. Pemetaan genangan banjir dilakukan dengan pemanfaatan citra satelit Sentinel-1 di bulan Maret, April, Juni, dan Agustus tahun 2017 (Gambar 3).

Sementara itu, identifikasi tutupan lahan (Gambar 4) yang memiliki potensi terdampak oleh genangan banjir menggunakan citra multi waktu Landsat-8 dengan komputasi awan (cloud computing). Klasifikasi tutupan lahan menggunakan aplikasi pembelajaran mesin dengan metode Classification and Regression Tree (CART). Hasil studi tersebut menunjukkan akurasi pemetaan yang cukup baik, yaitu $96.44 \%$ untuk pemetaan genangan 
banjir, dan $87.51 \%$ untuk pemetaan tutupan lahan.

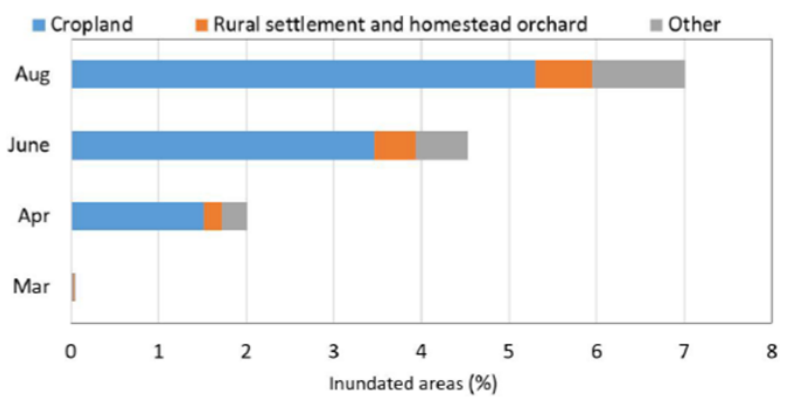

Gambar 3. Area Tutupan Lahan yang Terdampak Genangan Banjir (\%) (Sumber: Uddin et al., 2018)

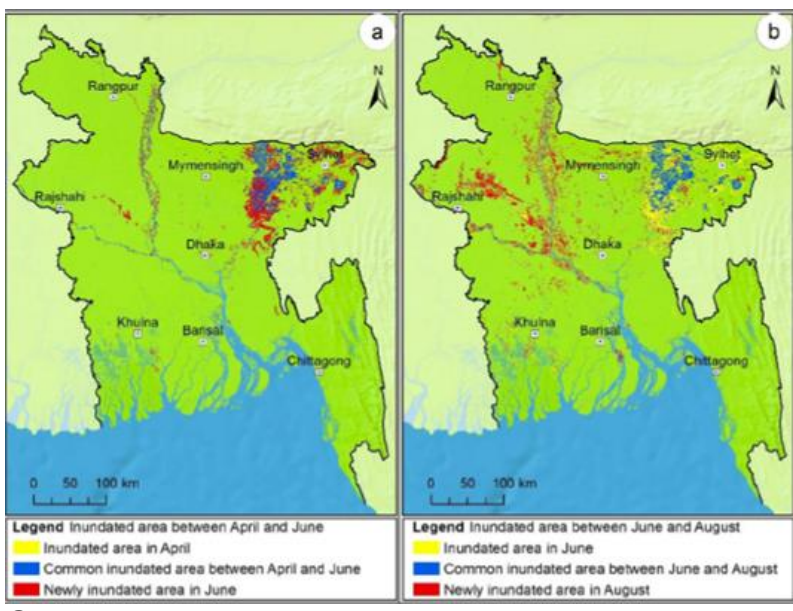

Gambar 4. Daerah Tergenang Banjir antara Bulan (a) April dan Juni, (b) Juni dan Agustus (Sumber: Uddin et al., 2018)

\subsection{Tantangan Pemanfaatan Big Data Citra Satelit}

Terkait dengan tantangan dalam pemanfaatan big data citra satelit ini, penulis mengelompokkan tantangan-tantangan tersebut terkait dengan beberapa isu. Isu tersebut meliputi penguasaan teknologi, analisis data, keamanan data, dan pengambil kebijakan.

\section{a. Penguasaan teknologi}

Analisis terhadap big data tidak hanya memerlukan perangkat lunak yang canggih, komputer yang super power, akan tetapi juga membutuhkan suatu keahlian terhadap pengolahan data. Hal ini terkait dengan uji coba pemodelan dan selanjutnya juga kemampuan dari analis dalam menyampaikan hasil kajian bagi pengguna. Hasil analisis bisa memberikan dampak yang positif dalam mengambil keputusan, memberi solusi yang optimal, juga pengetahuan yang mendalam, akan tetapi lebih dari itu keberhasilan dari hasil analisis sangat bergantung pada pengetahuan yang dapat tersampaikan tepat waktu dan tepat sasaran (Sun dan Scanlon, 2019).

\section{b. Analisis data}

Analisis spasial dan teknologi pemrosesan big data saat ini banyak menggunakan komputasi awan (cloud computing) di mana penyimpanan data dilakukan secara masif melalui internet. Melalui dukungan komputasi awan tersebut, pengguna dapat mengakses informasi dan data spasial tanpa terbatas waktu dan tempat, sekaligus juga dapat melakukan analisis spasial secara interaktif. Dengan demikian, dapat mempertajam kemampuan analisis dan meningkatkan kapasitas pemrosesan data yang cukup besar tanpa terkendala fasilitas komputer dengan spesifikasi yang tinggi. Namun demikian, pemrosesan sangat tergantung dengan jaringan internet yang memadai. Hal ini menjadi tantangan pada daerah dengan keterbatasan akses internet. Selain itu, untuk beberapa studi yang membutuhkan analisis secara real-time, metode kecerdasan buatan (artificial intelligence) yang efektif sangat dibutuhkan (Guo et al., 2017).

\section{c. Keamanan data}

Dengan segala penyimpanan dan analisis data pada cloud environment, hal ini menimbulkan pertanyaan apakah data dan algoritma tersimpan dengan aman. Selain itu juga data tersimpan secara sentral tanpa batasan administrasi kenegaraan (Sudmans et al., 2019). Dengan demikian data dapat berpotensi tersimpan di negara lain, sehingga penelitian yang terkait dengan stabilitas keamanan negara menjadi isu yang sangat penting.

\section{d. Pengambil Kebijakan}

Tantangan bagi pengambil kebijakan adalah pemahaman dan aksesibilitas dari hasil studi (Yang et al., 2019). Keterbukaan terhadap data, sumber, sistem, dan aspek lain dapat membantu pemanfaatan data citra satelit dalam menghadapi tantangan yang tidak dapat ditelusuri di masa lalu. Dalam hal ini, tentu saja membutuhkan perhatian pula dari sisi kebijakan. Untuk memfasilitasi keterbukaan data pada setiap daerah, diperlukan standarisasi kebijakan. 


\section{KESIMPULAN}

Disrupsi teknologi dengan hadirnya pemanfaatan big data citra satelit telah berkembang dengan pesat dan telah banyak dimanfaatkan dalam berbagai studi untuk menjawab dan memberikan solusi terhadap fenomena-fenomena alam. Salah satunya adalah pemanfaatan di bidang pengurangan risiko bencana. Ketersediaan data yang besar serta kemampuan analisis yang real-time mampu mendukung analisis multi waktu dan memberikan dampak yang positif dalam deteksi, pemantauan, dan prediksi suatu kejadian bencana. Hal ini sangat dibutuhkan untuk manajemen suatu bencana yang efektif dan efisien sehingga pengurangan risiko terhadap kejadian suatu bencana dapat tercapai.

Namun demikian, dalam hal analisis data yang cukup besar tersebut diperlukan pengetahuan dan penguasaan teknologi oleh seorang analis. Sehingga hasil dari analisis dapat dipertanggungjawabkan secara ilmiah dan memberikan dampak positif terkait pengambilan keputusan oleh para stakeholder. Lebih dari itu, pemanfaatan big data yang semakin terbuka dengan platform cloud environment membutuhkan suatu dukungan standarisasi kebijakan terhadap pemanfaatan data. Dengan demikian, data ataupun informasi hasil penelitian dapat dipergunakan dengan penuh tanggung jawab.

\section{PERSANTUNAN}

Penulis mengucapkan terima kasih kepada dewan redaksi serta reviewer atas masukan yang diberikan sehingga artikel ini dapat diterbitkan. Dengan ini, penulis menyampaikan bahwa artikel ini tidak menimbulkan potensi konflik kepentingan.

\section{DAFTAR PUSTAKA}

Breiman, L. 2001. Random Forests. Machine learning 45, no. 1: 5-32.

Celik, S, dan S. Corbacioglu. 2010. "Role of information in collective action in dynamic disaster environments." Disasters 34, no. 1: 137-154.

Centre for Research on the Epidemiology of Disasters (CRED). 2019. Natural Disaters 2017: Executive Summary. Institute Health and Society, Université Catholique de Louvain. Brussels. 8p.

Christensen, C.M., M.E. Raynor dan R. McDonald. 2015. What is Disruptive Innovation? Harvard Business Review,
December. [terhubung berkala]. https://hbr.org/2015/12/what-is-disruptiveinnovation [31 Oktober 2019].

Goodchild, M. F. 2013. The Quality of Big (Geo) Data. Dialogues in Human Geography, 3(3), 280-284.

Gorelick, N., M. Hancher, M. Dixon, S. llyushchenko, D. Thau, dan R. Moore. 2017. Google Earth Engine: Planetaryscale Geospatial Analysis for Everyone. Remote Sensing of Environment 202 (2017): 18-27.

Guo, H., Z. Liu, H. Jiang, C. Wang, J. Liu, dan D. Liang. 2017. Big Earth Data: A New Challenge and Opportunity for Digital Earth's Development. International Journal of Digital Earth 10, no. 1: 1-12.

ITU. 2019. Disruptive Technologies and Their Use in Disaster Risk Reduction and Management 2019. Telecommunication Development Bureau, International Telecommunication Union. Switzerland. $60 \mathrm{p}$.

Kempler, S., dan T. Mathews. 2017. Earth Science Data Analytics: Definitions, Techniques and Skills. Data Science Journal, 16.

Manning, C. D. 2015. Computational Linguistics and Deep Learning. Computational Linguistics, 41 (4), 701-707.

Melati, D. N. 2019. Multi Temporal Remotely Sensed Image Modelling for Deforestation Monitoring. Jurnal Alami: Jurnal Teknologi Reduksi Risiko Bencana, 3(1), 43-51.

Parks, S., L. Holsinger, M. Voss, R. Loehman, dan N. Robinson. 2018. Mean Composite Fire Severity Metrics Computed with Google Earth Engine Offer Improved Accuracy And Expanded Mapping Potential. Remote Sensing 10, no. 6: 879.

Sellars, S., P. Nguyen, W. Chu, X. Gao, K. Hsu, dan S. Sorooshian. 2013. Computational Earth Science: Big Data Transformed into Insight. EOS, Transactions American Geophysical Union 94, no. 32 (2013): 277278.

Sudmanns, M., D. Tiede, S. Lang, H. Bergstedt, G. Trost, H. Augustin, A. Baraldi, dan T. Blaschke. 2019. Big Earth Data: Disruptive Changes in Earth Observation Data Management and Analysis?. International Journal of Digital Earth: 1-19.

Sun, A. Y., dan B. R. Scanlon. 2019. How Can Big Data and Machine Learning Benefit Environment And Water Management: A Survey of Methods, Applications, and Future Directions. Environmental Research Letters. 
Uddin, K., M. A. Matin, dan F. J. Meyer. 2019. Operational Flood Mapping using Multitemporal Sentinel-1 SAR Images: A Case Study from Bangladesh. Remote Sensing 11, no. 13: 1581.

United Nation. 2015. Data-Pop Alliance Synthesis Report Big Data for Climate Change and Disaster Resilience: Realizing the Benefits for Developing Countries. [terhubung berkala] http://datapopalliance.org/wp-content/ uploads/2015/11/Big-Data-for-Resilience2015-Report.pdf [01 November 2019].

Wang, Z., D. Xiao, F. Fang, R. Govindan, C. C. Pain, dan Y. Guo. 2018. Model Identification of Reduced Order Fluid Dynamics Systems using Deep Learning. International Journal for Numerical Methods in Fluids, 86(4), 255-268.

Yang, C., M. Yu, Y. Li, F. Hu, Y. Jiang, Q. Liu, D. Sha, M. Xu, dan J. Gu. 2019. Big Earth Data Analytics: A Survey. Big Earth Data: 1-25.

Yu, B., F. Chen, dan S. Muhammad. 2018a. Analysis of Satellite-Derived Landslide at Central Nepal from 2011 to 2016. Environmental Earth Sciences 77, no. 9: 331.

Yu, M., C. Yang, dan Y. Li. 2018b. Big Data in Natural Disaster Management: A Review. Geosciences 8, no. 5: 165. 